\title{
Pengaruh Pemberian Kompos Kotoran Sapi Terhadap Pertumbuhan Anakan Salam (Syzygium Polyanthum) Di Persemaian
}

\author{
Kamaludin \\ Fakultas Pertanian Universitas Kapuas Sintang \\ e-mail : kamaludinkamal27@yahoo.co.id
}

\begin{abstract}
Abstrak: Penelitian ini bertujuan untuk mengetahui pengaruh komposisi kompos kotoran sapi yang terbaik dalam mempengaruhi pertumbuhan anakan Salam di persemaian. Hasil penelitian ini diharapkan dapat menambah ilmu dan pengetahuan terutama mengenai pengaruh kompos kotoran sapi terhadap pertumbuhan anakan Salam di persemaian. Metode yang digunakan dalam penelitian ini adalah pola dasar Rancangan Acak Lengkap (RAL) dengan perlakuan tunggal adalah komposisi media tanam yang terdiri dari 5 taraf yaitu : Tanah topsoil (T0) sebagai kontrol, Topsoil dan Kompos Kotoran sapi dengan dosis 150 gram per anakan (T1), Topsoil dan Kompos Kotoran Sapi dengan dosis 250 gram per anakan (T2), Topsoil dan Kompos Kotoran Sapi dengan dosis 350 gram per anakan (T3) dan Topsoil dan Kompos Kotoran Sapi dengan dosis 450 gram per anakan (T4).

Hasil penelitian menunjukan bahwa kompos kotoran sapi yang digunakan tidak berpengaruh secara signifikan terhadap pertambahan jumlah daun dan pertambahan tinggi anakan Salam di persemaian. Walaupun melalui hasil analisi sidik ragam tidak ada pengaruh yang signifikan, namun hasil pengukuran dan penghitungan diketahui bahwa perlakuan yang terbaik dalam memacu pertambahan jumlah daun dan tinggi anakan Salam adalah T4 (Kompos Kotoran sapi dengan dosis 450 gram per anakan) dengan rerata pertambahan jumlah daun sebanyak 17,40 helai dan rerata pertambahan tinggi $15,00 \mathrm{~cm}$.
\end{abstract}

Kata Kunci : Pertumbuhan, Anakan Salam dan Kompos Kotoran Sapi

\section{PENDAHULUAN}

Sejak lama masyarakat sekitar hutan menggantungkan hidupnya dari berbagai hasil hutan, baik hasil hutan berupa kayu maupun non kayu. Salah satu jenis tanaman kehutanan yang penting bagi masyarakat adalah tumbuhan Salam, Salam adalah nama tumbuhan yang merupakan penghasil rempah dan merupakan salah satu tanaman obat di Indonesia, Salam merupakan tumbuhan yang tumbuh liar di hutan dan juga banyak ditanam untuk menghasilkan daunnya.

Tumbuhan Salam sering kali dijumpai di perkarangan rumah maupun kebun dan tersebar hampir seluruh wilayah indonesia. Tumbuhan ini relatif mudah tumbuh dimana saja. Selain hal tersebut, Salam memiliki banyak khasiat dan manfaat yaitu khasiat sebagai bumbu masakan khas Indonesia, Sedangkan manfaat daun salam bagi kesehatan juga sudah 
banyak dibuktikan melalui penelitian resmi maupun independent. Kandungan zat gizi maupun zat non-gizi yang disebut fitronutrien merupakan kontributor utama khasiat daun salam untuk obat asam urat, kolesterol, menurunkan tekanan darah tinggi sampai membantu menurunkan berat badan.

Khasiat daun rempah yang satu ini dapat digunakan sebagai obat diare, sakit perut, kolesterol, maag akut sampai dibuat pasta gigi tradisional, selain itu tumbuhan salam merupakan salah satu jenis vegetasi penyusun tegakan hutan tropis Indonesia dengan kegunaan kayunya antara lain memenuhi spesifikasi tehnik untuk keperluan kayu pertukangan maupun energy, Kayu yang tergolong ke dalam kayu kelat (nama perdagangan) ini dapat dipergunakan sebagai bahan bangunan dan perabot rumah tangga, kekuatan kayu mungkin dapat juga diperhitungkan dari segi keawetan dan ketahananannya dan sudah dikenal pemanfaatan kulitnya sebagai salah satu bahan pewarna alami untuk tekstil, jaring maupun anyaman bambu sehingga bernilai ekonomis.

Walaupun tumbuhan Salam mempunyai banyak khasiat dan manfaatnya, di Kalimantan Barat Khususnya di Kabupaten Sintang sampai saat ini belum ada yang membudidayakan. Oleh karena itu, berbagai upaya harus dilakukan untuk menjamin kelestarian terutama melalui penyiapan bibit yang siap untuk ditanam. Salah satu tindakan upaya budidaya adalah menyiapkan media. Media yang sesuai sejak awal akan memacu dan memperbaiki pertumbuhan dari tanaman, sehingga pertumbuhannya menjadi lebih baik.

Kompos merupakan pupuk organik dari hasil pelapukan bahanbahan berupa dedaunan, jerami, alangalang, rumput, kotoran hewan, sampah kota dan sebagainya, salah satunya adalah kompos kotoran sapi, kompos ini terbentuk dengan adanya campur tangan manusia. Kompos telah banyak digunakan petani untuk membantu meningkatkan kesuburan tanah, sehingga akan berdampak terhadap peningkatan pertumbuhan hasil tanaman.

\section{METODOLOGI PENELITIAN}

Metode yang digunakan dalam penelitian ini adalah pola dasar Rancangan Acak Lengkap (RAL) dengan perlakuan tunggal adalah 
komposisi media tanam yang terdiri dari 4 taraf yaitu : Tanah topsoil (T0) sebagai kontrol, Kompos Kotoran sapi dengan dosis 150 gram per anakan (T1), Kompos Kotoran Sapi dengan dosis 250 gram per anakan (T2), Kompos Kotoran Sapi dengan dosis 350 gram per anakan (T3) dan Kompos Kotoran Sapi dengan dosis 450 gram per anakan (T4). Rancangan ini dipilih karena anakan salam yang digunakan dalam penelitian relatif homogen (seragam).

Jumlah populasi dalam penelitian ini adalah 5 taraf perlakuan komposisi media tanam, masing-masing perlakuan diulang sebanyak 5 kali dan setiap ulangan terdapat 4 anakan, sehingga terdapat 100 anakan Salam. Sampel dalam penelitian ini diambil sebanyak 2 anakan setiap ulangan sehingga anakan Salam yang diamati sebanyak 5 perlakuan x 5 ulangan $\times 2$ anakan $=50$ anakan.

\section{Bahan dan Alat Penelitian}

Bahan yang digunakan dalam penelitian ini terdiri dari

Anakan Salam dengan tinggi, diameter batang dan jumlah daun yang sama digunakan sebagai objek penelitian, Kompos Kotoran Sapi, Air, digunakan untuk menyiram anakan Salam selama penelitian; Polybag ukuran 15 x $30 \mathrm{~cm}$, digunakan untuk menanam anakan Salam, Paranet dengan intensitas 50\% digunakan sebagai atap naungan pembibitan;

Adapun alat-alat yang digunakan terdiri dari Parang, cangkul, Gembor, Kamera, Alat tulis/buku, Mistar ukur, Timbangan, Gelas minuman mineral, Kayu dan papan.

\section{HASIL DAN PEMBAHASAN}

\section{Hasil Penelitian}

Untuk mengetahui pertambahan jumlah daun anakan Salam selama penelitian, maka dilakukan penghitungan yaitu dengan cara mengurangi jumlah daun anakan Salam pada akhir penelitian dengan jumlah daun pada awal penelitian Data hasil penghitungan rerata pertambahan jumlah daun anakan Salam selama penelitian dapat dilihat pada tabel 4.1. Selanjutnya berdasarkan data sebagaimana tabel 4.1, maka dilakukan analisis sidik ragam. Data hasil analisis sidik ragam mengenai uji pertumbuhan anakan Salam pada berbagai komposisi kompos kotoran sapi di persemaian terhadap pertambahan jumlah daun dapat dilihat pada tabel 1 . 
Tabel .1. Data Rerata Pertambahan Jumlah Daun Anakan Salam

\begin{tabular}{|c|c|c|c|c|c|c|c|}
\hline \multirow{2}{*}{ Perlakuan } & \multicolumn{6}{|c|}{ Ulangan } & \multirow{2}{*}{ Rerata } \\
\hline & 1 & 2 & 3 & 4 & 5 & Jumlah & \\
\hline T0 & 22,00 & 10,00 & 13,50 & 9,50 & 14,00 & 69,00 & 13,80 \\
\hline $\mathrm{T} 1$ & 17,00 & 11,50 & 13,50 & 18,00 & 14,00 & 74,00 & 14,80 \\
\hline $\mathrm{T} 2$ & 13,00 & 17,00 & 18,50 & 14,50 & 13,00 & 76,00 & 15,20 \\
\hline $\mathrm{T} 3$ & 19,50 & 13,00 & 14,00 & 19,00 & 12,00 & 77,50 & 15,50 \\
\hline $\mathrm{T} 4$ & 16,00 & 19,50 & 13,00 & 16,50 & 22,00 & 87,00 & 17,40 \\
\hline Jumlah & 87,50 & 71,00 & 72,50 & 77,50 & 75,00 & 383,50 & 76,70 \\
\hline
\end{tabular}

Tabel 2. Analisis Sidik Ragam Uji Pertumbuhan Anakan Salam Pada Berbagai Komposisi Kompos Kotoran Sapi Terhadap Pertambahan Jumlah Daun Di Persemaian

\begin{tabular}{|c|c|c|c|c|cc|}
\hline $\begin{array}{c}\text { Sumber } \\
\text { Keragaman }\end{array}$ & $\begin{array}{c}\text { Derajat } \\
\text { Bebas }\end{array}$ & $\begin{array}{c}\text { Jumlah } \\
\text { Kuadrat }\end{array}$ & $\begin{array}{c}\text { Kuadrat } \\
\text { Tengah }\end{array}$ & \multirow{2}{*}{ F. Hitung } & \multicolumn{2}{|c|}{ F. tabel } \\
\cline { 1 - 4 } Perlakuan & 4 & 34,76 & 8,69 & $0,69^{\text {ns }}$ & 2,87 & 4,43 \\
\hline Galat & 20 & 249,6 & 12,48 & & & \\
\cline { 1 - 2 } Total & 24 & 284.36 & & & \\
\hline \multicolumn{7}{c}{ KK $=4,6 \%$} \\
\end{tabular}

Keterangan : ns : Tidak Berpengaruh Signifikan

Berdasarkan hasil analisis sidik ragam pada tabel 2 tersebut, diketahui bahwa seluruh komposisi kompos kotoran sapi yang digunakan tidak memberikan pengaruh yang signifikan terhadap pertambahan jumlah daun anakan Salam selama kegiatan penelitian. Oleh karena tidak adanya pengaruh yang signifikan dalam penggunaan kompos kotoran sapi terhadap pertambahan jumlah daun, maka tidak dilakukan uji lanjut untuk mengetahui komposisi yang terbaik dalam mempengaruhi pertambahan jumlah daun anakan Salam. 
Tabel 3. Data Rerata Pertambahan Tinggi Anakan Salam Selama Penelitian Di Persemaian

\begin{tabular}{|c|c|c|c|c|c|c|c|}
\hline \multirow[b]{2}{*}{ Perlakuan } & \multicolumn{5}{|c|}{ Ulangan } & \multirow{2}{*}{ Jumlah } & \multirow{2}{*}{ Rerata } \\
\hline & 1 & 2 & 3 & 4 & 5 & & \\
\hline T0 & 14,50 & 9,00 & 10,50 & 10,00 & 11,00 & 55,00 & 11,00 \\
\hline $\mathrm{T} 1$ & 13,50 & 6,50 & 10,50 & 17,50 & 11,00 & 59,00 & 11,80 \\
\hline $\mathrm{T} 2$ & 16,00 & 12,00 & 12,00 & 11,00 & 14,00 & 65,00 & 13,00 \\
\hline T3 & 12,00 & 16,00 & 10,50 & 14,00 & 14,50 & 67,00 & 13,40 \\
\hline $\mathrm{T} 4$ & 16,00 & 17,00 & 10,00 & 14,00 & 18,00 & 75,00 & 15,00 \\
\hline Jumlah & 72,00 & 60,50 & 53,50 & 66,50 & 68,50 & 321,00 & 64,20 \\
\hline
\end{tabular}

Tabel 4. Analisis Sidik Ragam Uji Pertumbuhan Anakan Salam Pada Berbagai Komposisi Kompos Kotoran Sapi Terhadap Pertambahan Tinggi Di Persemaian

\begin{tabular}{|c|c|c|c|c|c|c|}
\hline $\begin{array}{c}\text { Sumber } \\
\text { Keragaman }\end{array}$ & $\begin{array}{c}\text { Derajat } \\
\text { Bebas }\end{array}$ & $\begin{array}{c}\text { Jumlah } \\
\text { Kuadrat }\end{array}$ & $\begin{array}{c}\text { Kuadrat } \\
\text { Tengah }\end{array}$ & F. Hitung & \multicolumn{2}{|c|}{ F. tabel } \\
\cline { 1 - 4 } Perlakuan & 4 & 47,36 & 11,84 & $1,49^{\text {ns }}$ & 2,87 & 4,43 \\
\hline Galat & 20 & 158 & 7,90 & & & \\
\hline Total & 24 & 205,36 & & & & \\
\hline
\end{tabular}

Keterangan : ns : Tidak Berpengaruh Signifikan

Berdasarkan hasil analisis sidik ragam pada tabel 4 tersebut diatas, diketahui bahwa seluruh komposisi kompos kotoran sapi yang digunakan tidak memberikan pengaruh yang signifikan terhadap pertambahan tinggi anakan Salam selama kegiatan penelitian. Oleh karena tidak adanya pengaruh yang signifikan dalam penggunaan berbagai komposisi kompos kotoran sapi terhadap pertambahan tinggi, maka tidak dilakukan uji lanjut untuk mengetahui komposisi yang terbaik dalam mempengaruhi pertambahan tinggi anakan Salam.

\section{Pembahasan}

Berdasarkan hasil analisis sidik ragam sebagaimana tabel 4.2 diketahui bahwa seluruh perlakuan berupa berbagai komposisi kompos kotoran sapi yang diberikan tidak memberikan pengaruh yang signifikan terhadap pertambahan jumlah daun anakan Salam di persemaian. Hasil analisis sidik ragam yang menunjukan tidak signifikannya pertambahan jumlah daun anakan Salam bukan berarti tidak terjadi 
pertumbuhan, tetapi maksudnya pertumbuhan jumlah daun setelah dianalisis secara matematis tidak signifikan padahal secara visual terlihat dengan jelas adanya perbedaan pertumbuhan jumlah daun pada anakan Salam sesuai dengan komposisi kompos kotoran sapi yang diberikan.

Berdasarkan tabel 1. diketahui bahwa kompos kotoran sapi yang diberikan mampu memicu pertumbuhan berupa pertambahan jumlah daun anakan Salam. Pertambahan jumlah daun yang terbaik secara berurutan adalah T4 (Kompos Kotoran Sapi dengan dosis 450 gram per anakan) dengan rerata pertambahan 17,40 helai, T3 (Kompos Kotoran Sapi dengan dosis 350 gram) rerata pertambahan 15,50 helai, T2 (Kompos Kotoran Sapi dengan dosis 250 gram per anakan) rerata pertambahan 15,20 helai, T1 (Kompos Kotoran Sapi dengan dosis 150 gram per anakan) rerata pertambahan 14,80 helai, T0 (Tanah topsoil tanpa Kompos Kotoran Sapi) rerata pertambahan 13,80 helai. Jumlah pertambahan jumlah daun untuk jenis pohon ini dianggap cukup banyak karena jika dikalkurasikan berarti setiap bulan tumbuh 4-5 helai daun baru.
Hasil penelitian diketahui bahwa perlakuan T4 (Kompos Kotoran Sapi dengan dosis 450 gram per anakan) adalah yang terbaik dalam memacu pertumbuhan berupa pertambahan jumlah daun anakan Salam dibandingkan dengan perlakukan lainnya. Hal ini memberikan indikasi bahwa semakin banyak kompos kotoran sapi yang diberikan maka semakin baik pertumbuhan anakan salam. Dugaan ini diperkuat sebagaimana hasil penelitian yang menunjukan perlakuan T3 (Kompos Kotoran Sapi dengan dosis 350 gram) lebih baik kemampuan memacu pertumbuhan daun dibandingkan perlakuan T2 (Kompos Kotoran Sapi dengan dosis 250 gram per anakan), T1 (Kompos Kotoran Sapi dengan dosis 150 gram per anakan), T0 (Tanah topsoil tanpa Kompos Kotoran Sapi).

\section{Pertambahan Tinggi Anakan Salam}

Berdasarkan hasil analisi sidik ragam sebagaimana yang terlihat tabel 4, diketahui bahwa kompos kotoran sapi yang digunakan tidak memberikan pengaruh yang signifikan terhadap pertambahan tinggi anakan Salam. Walaupun demikian secara visual dan berdasarkan hasil pengukuran diketahui bahwa telah terjadi pertumbuhan berupa PIPER No.25 Volume 13 Oktober 2017 
pertambahan tinggi anakan Salam.

Rerata pertambahan tinggi anakan

Salam yang terbaik secara berurutan adalah perlakuan T4 (Kompos Kotoran Sapi dengan dosis 450 gram per anakan) dengan rerata pertambahan tinggi 15,00 cm, T3 (Kompos Kotoran Sapi dengan dosis 350 gram per anakan) rerata pertambahan tinggi 13,40 cm, T2 (Kompos Kotoran Sapi dengan dosis 250 gram per anakan) rerata pertambahan tinggi $13,00 \mathrm{~cm}, \mathrm{~T} 1$ (Kompos Kotoran Sapi dengan dosis 150 gram per anakan) rerata pertambahan tinggi $11,80 \mathrm{~cm}, \quad$ T0 (Tanah topsoil tanpa Kompos Kotoran Sapi) rerata pertambahan tinggi 11,00 $\mathrm{cm}$. Dengan demikian rerata pertambahan tinggi bulanan anakan Salam selama penelitian berkisar antara $3,5 \mathrm{~cm}-5 \mathrm{~cm}$.

Hasil penelitian terhadap pertambahan tinggi anakan yang diamati, sama seperti pertambahan daun yaitu bahwa dosis kompos kotoran sapi terbesar adalah komposisi yang terbaik dibandingkan dengan tanpa pemberian kompos kotoran sapi. Indikasi ini terlihat dengan jelas bahwa semakin besar dosis yang digunakan, maka semakin baik pertumbuhan. Walaupun demikian hal ini belum dapat dipastikan karena tidak dilakukan analisis terhadap media tanam yang digunakan, sehingga kesimpulan yang diambil hanyalah berupa asumsi berdasarkan pengamatan di lapangan melalui proses penelitian.

Pertumbuhan tumbuhan (tinggi) secara umum sangat dipengaruhi oleh ketersediaan unsur hara pada komposisi kompos kotoran sapi. Jika unsur hara tersedia dalam jumlah yang cukup maka pertumbuhan akan terjadi secara optimal sebaliknya jika kekurangan unsur hara maka pertumbuhan dan perkembangannya menjadi terhambat. Unsur hara yang terpenting dalam memacu pertumbuhan adalah unsur hara makro yaitu N,P dan K, karena menurut (Sarief, 1981:45) dari semua unsur hara yang dibutuhkan oleh tanaman, unsur $\mathrm{N}, \mathrm{P}$, dan $\mathrm{K}$ merupakan unsur-unsur utama yang diperlukan dalam jumlah yang paling banyak.

Unsur hara N,P, dan $\mathrm{K}$ sangat berguna untuk menambah tinggi tanaman. Unsur $\mathrm{N}$ diperlukan untuk merangsang pertumbuhan terutama daun dan pertambahan tinggi tanaman. Unsur hara $\mathrm{P}$ digunakan untuk mempercepat pertumbuhan akar dan unsur hara $\mathrm{K}$ merupakan sebagai pengimbang pengaruh unsur $\mathrm{N}$ dan $\mathrm{P}$ yang berfungsi untuk pembentukan 
protein dan karbohidrat serta mengeraskan bagian kayu. Bertambah tingginya tanaman disebabkan oleh terjadinya pembelahan dan perpanjangan sel pada daerah meristem ujung tunas dan ujung akar.

\section{Uji Hipotesis}

Hipotesis yang dikemukakan dalam penelitian ini adalah :

$\mathrm{H}_{0}=$ Diduga pemberian kompos kotoran sapi tidak memberikan pengaruh yang signifikan terhadap pertumbuhan anakan Salam di persemaian.

$\mathrm{H}_{1}=$ Diduga pemberian kompos kotoran sapi memberikan pengaruh yang signifikan terhadap pertumbuhan anakan Salam di persemaian.

Berdasarkan hasil analisis sidik ragam terhadap semua variabel yang diamati, yaitu pertambahan jumlah daun dan pertambahan tinggi anakan Salam di persemaian diketahui bahwa kompos kotoran sapi yang digunakan tidak memberikan pengaruh yang signifikan terhadap pertambahan jumlah daun dan pertambahan tinggi anakan Salam di persemaian. Dengan demikian maka hipotesis yang diajukan ditolak (terima Ho dan tolak $\mathrm{H}_{1}$ )

\section{Kesimpulan}

Berdasaran hasil penelitian dan pengamatan, maka dapat disimpulkan sebagai berikut:

1. Kompos kotoran sapi yang digunakan tidak berpengaruh secara signifikan terhadap pertambahan jumlah daun dan pertambahan tinggi anakan Salam di Persemaian.

2. Walaupun melalui hasil analisis sidik ragam tidak pengaruh yang signifikan, namun hasil pengukuran dan penghitungan diketahui bahwa perlakuan yang terbaik dalam memacu pertambahan jumlah daun dan tinggi anakan Salam adalah T4 (Kompos Kotoran Sapi dengan dosis 450 gram per anakan) dengan rerata pertambahan jumlah daun sebanyak 17,40 helai dan rerata pertambahan tinggi $15,00 \mathrm{~cm}$.

\section{Saran}

Perlu dilakukan kajian yang lebih mendalam untuk melihat pengaruh kompos kotoran sapi terhadap pertumbuhan anakan Salam yaitu dengan cara menambah besarnya dosis kompos yang digunakan dan menambah lamanya waktu penelitian, sehingga didapatkan kesimpulan yang komprehensif. 
DAFTAR PUSTAKA

Dalimartha Setiawan. 2000. Atlas

Tumbuhan Obat

Indonesia. Bogor : Trobus Agriwidya.

Departemen Kehutanan dan

Perkebunan. 1999.

Panduan Kehutanan

Indonesia. Departemen

Kehutanan dan

Perkebunan Republik

Indonesia. Jakarta.

Hanafiah, KA. 2008. Rancangan

Percobaan. Jakarta :

PT.Raja Grafindo Persada.

Hendra Murfi. 2016. Pengaruh

Pemberian Kompos dan

Kotoran Kambing

terhadap Pertumbuhan
Anakan Cerindak

(Shorea seminis) Di

persemaian. Jurusan

Kehutanan Universitas

Kapuas. Sintang.

http://cara.pro/cara-membuat-pupuk-

kompos-dari-kotoran-

sapi/.2016.

Lingga, P. 2010. Petunjuk

Penggunaan Pupuk.

Penebar Swadaya.

Murbandono L. 2005. Membuat

Kompos. Penebar

Swadaya. Jakarta.

Sopian. 2007. Cara Praktis Membuat

Kompos. Jakarta :

AgroMedia Pustaka.

Van Steenis, C.G.G.J. 2003. Flora.

Jakarta : Pradya Paramita. 